\title{
COMPARATIVE AND HISTORICAL STUDY OF TOPONOMIC MYTH AND LEGENDS IN THE “HISTORY OF BUKHARA" BY ABU BAKR NARSHAKHI
}

\section{Tukhtamurod Olimovich Kuchkarov}

Associate Professor Jizzakh Branch Of The National University Of Uzbekistan

\section{ABSTRACT}

This article examines the genesis and artistic evolution of epic plots in medieval written sources in the study of Uzbek folk toponymic prose.

KEYWORDS: - Legend, myth, saying, fable, tale, "History of Bukhara”, "Badiai khurdak", "Owner of peacock", "Mokh", "Afrasiab".

\section{INTRODUCTION}

The study of the historical development and artistic evolution of epic plots preserved through written sources has important scientific value in covering the evolution of a particular folklore work over several centuries, as well as in determining the genesis and formation process of epic works recorded directly during live performance. In order to show the place of folklore works included in medieval written sources in the historical evolution of the plot system of Uzbek folk toponymic myths and legends in this scientific information, we analyzed the materials of folklore in the book
"History of Bukhara" by the talented historian of the X century Abu Bakr Muhammad ibn Jafar Narshakhi

Originally born and raised in the village of Narshakhi near Bukhara, Abu Bakr Narshakhi wrote his famous History of Bukhara in 943-944 after gaining a comprehensive knowledge of the history, geography, ethnography and literature of the peoples and countries of the East. This work is included in the scientific and historical literature "History of Narshakhi" ("History of Narshakhi"), "History of Bukhara" ("History of Bukhara"), "Tahqiq ul-viloyat" ("Determining the truth of the region"), "News of Bukhara" ("About Bukhara"). messages"). However, the well-known name "History of Bukhara" fully corresponds to the 
CURRENT RESEARCH JOURNAL OF PHILOLOGICAL SCIENCES 2(12):

62-66, December 2021

DOI: https://doi.org/10.37547/philological-crjps-02-12-13

ISSN 2767-3758

(C)2021 Master Journals

Crossref do

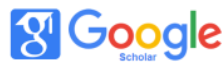

Accepted08th December, 2021 \& Published $13^{\text {th }}$ December, 2021

essence of this work.

The great historian tells about the history of Bukhara, the description of the surrounding villages, the city's guzars, monuments, its peculiarities, rulers and events that took place here, as well as the use of original historical and geographical works, as well as folklore materials. , in particular, refers many times to myths, legends, parables, parables, and stories. The scholar's skill in the effective use of folklore sources is especially evident in places where the need to interpret the meaning of a place name arises.

Abu Bakr Narshakhi used two different methods to convey the myths and legends associated with place names. According to the first method, the historian refers to epic works that have been popularized orally among the people in order to prove that the name of a particular place has a history of origin or that it was once called by another name. For example, in the chapter devoted to the description of Karmana, he writes that in order to prove that the place was formerly called "Bodyayi khurdak", "The parable says that in ancient times Carmina was called" Bodyayi khurdak "("Bowl") [1]. Here the word "parable" is used in the genre of folklore, that is, in the sense of narration, narration, legend. Elsewhere, the historian uses terms and phrases such as "narrative," and "narrated," when referring to examples of folk prose.

\section{THE MAIN FINDINGS AND RESULTS}

The second way in which a historian uses folklore material is to quote the text of a particular narration, myth, or oral story in full, or to narrate its content briefly. In our opinion, before writing his work, Ambu Bakr Narshakhi not only studied the existing historical and geographical literature, but also traveled to Bukhara and surrounding villages, told toponymic legends and myths, as well as the events in the oasis and lived in this area also collected historical myths and legends narrating the activities of real historical figures. When writing "History of Bukhara", he widely used these folklore materials as an "oral historical source". For example, in the History of Bukhara we read about the village of Tavois in the present-day Kyzyltepa district: "Yana Tavois. He is from Bukhara region and his real name is Arkud. It was inhabited by people who loved the rich and beautiful. Since Zebu was given ornaments, everyone kept one or two peacocks in his house for ornaments. When the Arabs (before coming here) had not seen the peacock before, they saw many peacocks here, and called the village "Zot ut-tavois" - "Owner of the Peacocks," but its original name has been forgotten; who later dropped the word "zot" and renamed it "Tavois" (p. 20).

The toponymic legend about the origin of the name of the market "Bozori Moh Roz", which existed in Bukhara in the $\mathrm{X}$ century, shows that in ancient times the tradition of monism, ie the cult of the moon, was widespread among the population of this region. According to Narshakhi, "This market existed in our time; I would be very surprised why such a habit was painted; From the elders and sheikhs of Bukhara: "What is the reason for this?" I asked. They replied, "In ancient times, the people of Bukhara were idolaters, and this market was a picture. It is noteworthy that the above passage contains information confirming that the legends and myths that served as an "oral historical source" for Narshakhi were recorded directly during the live performance. This is the story of the author's question to the "elders and sheikhs of Bukhara" about the origin of the name Moh Bazaar.

Narshakhi not only describes a popular example of a toponymic prose about the origin of the name Moh Bazaar, but also cites other versions of the plot for comparison. According to $\mathrm{Abu}$ al-Hasan 
CURRENT RESEARCH JOURNAL OF PHILOLOGICAL SCIENCES 2(12):

62-66, December 2021

DOI: https://doi.org/10.37547/philological-crjps-02-12-13

ISSN 2767-3758

(C)2021 Master Journals

Crossref do

gil Google

Accepted08th December, 2021 \& Published $13^{\text {th }}$ December, 2021

Nishapuri in his book Khazain ul-Ulum, Narshakhi writes, in ancient times there was a king in Bukhara whose name was Moh. He ordered that this market be built; by his decree the carpenters and painters from that year to this year made idols, brought them to this market on the appointed day, and sold them, and the people bought them. Whenever that idol was lost or broken, or worn out, they would buy another one on that Sunday and throw away the old one. Nowadays, where the Moh Mosque is located, there is a tree-lined plain by a large canal, and there is a market in the shade of these trees. He was a king, so that the people would be interested in buying an idol, so he would come to this market and sit on a throne where the Moh Mosque is now located, and everyone would buy an idol for himself and take it home. This place was again the temple of the firefighters (too); on Sundays, when people gathered here, they would all enter the temple and worship the fire. This temple existed until the time of Islam, and when the Muslims were strengthened, they built this (Moh) mosque in the same place. Now it is one of the most prestigious mosques in Bukhara "(pp. 26-27).

The ancient temple in Bukhara and the market next to it are called "Moh" due to the fact that among our ancestors, who once lived in Central Asia, there was a tradition of worshiping the moon, sun and stars monism or crescentism. Historian A.M. Belenitsky notes that monastic temples were also built in Central Asia, where magical rituals associated with the glorification of celestial lights were performed [2]. Archaeologists have discovered that the coins used during the Kushan period depicted the image of the "Moon", "Mokh", the god of the moon [3].

The most characteristic example of toponymic prose in the "History of Bukhara" is the legend of Romitan. The construction of Romtin (i.e. Romitan), which is considered to be "a village with a large ditch and a strong fortress," was narrated by Abu
Bakr Narshakhi based on a narration he heard directly from the people: "This village was built by Afrosiab. Whenever Afrosiab came to this province, he did not live anywhere other than this village. According to the books of the Persians, Afrosiab lived for two thousand years. He is a witch and is one of the children of King Noah. She killed her sonin-law named Siyavush. Siyavush had a son named Kaykhusrav, and when he came to this province with a large army demanding his father's blood, Afrosiab was besieging the village of Romtin. Kaykhusrav and his army surrounded the fortress for two years and built a village in front of it, which he named Romush. He was called Romush out of kindness. This village is still prosperous. Kaykhusrav built a temple of fire-worshipers in the village of Romush; firefighters say the temple is the oldest of the Bukhara firefighters' temples. Two years later, Kaykhusrav captured and killed Afrosiab. The tomb of Afrosiab is on a large hill adjacent to the hill of the late Imam Abu Hafz Kabir at the gate of the Temple in Bukhara. The people of Bukhara composed wonderful songs about the murder of Siyavush; the singers call these songs "Kini Siyavush" - "Battle of Siyavush" (pp. 23-24).

This narration is very short in size, and at the center of its plot is a message-motif that serves to inform about the creation of Romitan by Afrosiab. In our view, it is possible that Abu Bakr Narshakhi heard and even recorded this narration from a narrator during a live performance. Because the original interpretation of the plot of this legend about the origin of the name of the place was found in the system of epic works of Uzbek folklore in the twentieth century. The content of this narration written by M. Juraev in 1991 from Sharifa bibi Maqul qizi, living in Shafirkan district of Bukhara region, is as follows: He had a beautiful daughter. One day a witch appeared in the king's palace. He deceitfully deceived the people in the palace, went to the princess, and presented the girl with a 
CURRENT RESEARCH JOURNAL OF PHILOLOGICAL SCIENCES 2(12):

62-66, December 2021

DOI: https://doi.org/10.37547/philological-crjps-02-12-13

ISSN 2767-3758

(C)2021 Master Journals

Crossref do

gil Google

Accepted08 ${ }^{\text {th }}$ December, 2021 \& Published $13^{\text {th }}$ December, 2021

strange mirror. As the king's daughter tried to comb her hair in the mirror, she suddenly had a headache. His headache did not subside. Afrosiab gathered all the doctors in the country and ordered his daughter to be treated. But no one was able to cure the king's daughter. Then Afrosiab took his daughter on a journey. "If he could rest in the most beautiful villages of the country, the headaches would go away," he thought. They walked and walked and walked and walked, and at last they came to a picturesque village surrounded by beautiful gardens. The village fell in love with the king's daughter, and when she arrived, her headache was cured. Afrosiab was happy and built a fortress in this village. The castle has become a beautiful place where the king's daughter lives. Because the king's daughter was healed here, the place was called Oromitan, meaning the resting place of the coin. It was later renamed Romitan.

It is known that the images of Afrosiab, Siyavush and Kaykhusrav are among the traditional characters of Uzbek historical legends and myths. In our opinion, the epic plots of our ancestors about Afrosiab must have played an important role in the formation of the legend about the establishment of Romitan. Because the legends about the adventures of Afrosiab and Siyavush were widespread among the peoples of Central Asia. In the mythology of our ancient ancestors, Siyavush was interpreted as a mythical character who embodied the cult of the dying nature. Abu Bakr Narshakhi himself mentioned the existence of shrines and shrines associated with the Siyavush cult during the narration of the narration about the construction of the Bukhara arch. Legends and myths about Afrosiab and Siyavush arose as a result of the artistic evolution of epic plots, which appeared on the basis of the great written monument mythological plots "Avesto" and played an important role in the formation of artistic thought of the ancient East. The example of Romitan in the
"History of Bukhara" tells about the battle of Afrosiab and Kaykhusrav, and this plot is also present in the "Avesto" alchemy called "Zamyad yasht". It tells of Khaosrava, that is, of Kaykhusrav's father, Syavarshan, that of Siyavush, who went to war against Frangharation in revenge for his murder:

Kayoniy Chaosrava

With Razil Nereman

They competed on horseback.

Along the way,

The ambush,

Save yourself from the trap,

Ruler Xaosrava,

He gave tattoos to enemies,

Ugly Frangration,

And that Kersavazd

He was caught in the fight.

Killed by deceit

His father was Syavarshan

And in the hands of Frasyak

Destroyed Agraerat-

From the seeds of Naravid

An immortal hero who came out

Blood rights - revenge [4].

From the analysis of this poetic text, it is clear that there is a similarity and commonality between the narrative of the epic plot about the battle between Afrosiab and Kaykhusrav narrated by Abu Bakr Narshakhi and the mythical plots of the Avesto.

In addition, the following narration in the work of the famous linguist Mahmud Kashgari Dīwān Lughāt al-Turk confirms that the original interpretation of the epic plot about the construction of a beautiful house for his daughter by Afrosiab was widespread in the folklore of the Turkic peoples of Central Asia in the X-XI centuries. This is how he built the city of Qazvin. The word originally meant goosebumps - a place where geese 
CURRENT RESEARCH JOURNAL OF PHILOLOGICAL SCIENCES 2(12):

62-66, December 2021

DOI: https://doi.org/10.37547/philological-crjps-02-12-13

ISSN 2767-3758

(C)2021 Master Journals

crossref do) :810 Google

Accepted08 ${ }^{\text {th }}$ December, 2021 \& Published $13^{\text {th }}$ December, 2021

play. Because he would stay here and play here. That is why some Turks considered Qazvin to be one of the Turkish cities. The city of Qom is also a frontier. Because sand is a Turkish word. Afrosiab's daughter used to hunt and play here [5]. "

Mahmud Kashgari, in order to explain the meaning of the word "goose", adds the following information that complements the above narration: "Some considered the whole of Movaraunnahr to be a Turkic land. It starts in Jankand. One of his horses is Dizrujin. It means copper city according to its yellowness. It is close to Bukhara. Here Siyavush, the daughter of Afrasiab, the husband of Qazvin, was killed. Pagan-firefighters come here one day every year and cry around the place where Siyavush is. Cattle are slaughtered and sacrificed. The blood of the slaughtered animal is poured on top of his grave. That's their habit [6]."

\section{Conclusion}

In our opinion, the epic works dedicated to the adventures of Afrosiab and Siyavush were widely popular in the historical and folklore process of the $\mathrm{X}$-XI centuries, the authors who created the written sources of that period used legends and myths narrated directly by the narrators to explain the meaning of certain place names and to shed light on the history of the creation of towns and villages.

\section{REFERENCES}

1. Abu Bakr Mohammad ibn Jaafar Narkhashiy.The History of Bukhara.Tashkent, Sciense 1966. - Б.20 (All the links taken from this sourse will be highlihgtened in brakets with the page numbers- auther ).

2. A.M. Belenitsky Ideological issues ond traditions of Sogds. (according to the materials of Pandjikent) // Art of ancient
Panjikent. - M., 1954. - P.48.

3. Pugachenskiy.G.A. Rempel.L. Art history of Uzbekistan. - M., 1965. - p.173 (fig.56).

4. Avesto.Zamyad yasht Kharno's praise // Uzbek language and literature. - Tashkent, 2000. - 4-vol. - P.60.

5. Makhmud Koshgariy. Dīwān Lughāt al-Turk.. 3-vol. - Tashkent, 1963, 163-page.

6. Dīwān Lughāt al-Turk. page-164 